\title{
Control of Postharvest Gray Mold of Table Grapes in the San Joaquin Valley of California by Fungicides Applied During the Growing Season
}

\author{
J. L. Smilanick and M. F. Mansour, USDA ARS San Joaquin Valley Agricultural Sciences Center, 9611 South Riv- \\ erbend Avenue, Parlier, CA 93648; F. Mlikota Gabler, Institute for Adriatic Crops, 21000 Split, Croatia; \\ D. A. Margosan, USDA ARS San Joaquin Valley Agricultural Sciences Center, 9611 South Riverbend Avenue, Par- \\ lier, CA 93648; and J. Hashim-Buckey, University of California, Cooperative Extension Kern County, 1031 South \\ Mount Vernon Avenue, Bakersfield 93307
}

\begin{abstract}
Smilanick, J. L., Mansour, M. F., Mlikota Gabler, F., Margosan, D. A., and Hashim-Buckey, J. 2010. Control of postharvest gray mold of table grapes in the San Joaquin Valley of California by fungicides applied during the growing season. Plant Dis. 94:250-257.

Fungicides applied before harvest were evaluated to control postharvest gray mold of table grapes, caused by Botrytis cinerea. The concentrations of thiophanate methyl (THM), iprodione (IPR), cyprodinil (CYP), pyraclostrobin + boscalid (PS+BO), pyrimethanil (PYR), or fenhexamid (FEN) that inhibited the growth of four isolates sensitive to these fungicides by $50 \%$ $\left(\mathrm{EC}_{50}\right)$ were $12.4,2.5,0.61,0.29 / 0.57,0.26$, or $0.17 \mathrm{mg} \mathrm{liter}^{-1}$, respectively. THM, IPR, CYP, PS+BO, PYR, or FEN were applied to detached 'Thompson Seedless' berries at the equivalent of the maximum approved rates of $600,500,270,59 / 116,370$, or $290 \mathrm{mg} \mathrm{liter}^{-1}$, respectively, except PS+BO, which were used at $54.2 \%$ of their current registered maximum rates. The berries were inoculated with $B$. cinerea 48 or $24 \mathrm{~h}$ before treatment or 24 or $48 \mathrm{~h}$ after treatment. Gray mold 2 weeks after treatment and storage at $15^{\circ} \mathrm{C}$ was lowest after FEN application, followed by PYR, CYP, IPR, PS+BO, and THM. In commercial vineyards, one application of FEN, PYR, $\mathrm{CYP}$, or PS+BO, all at their current maximum approved rates, 2 weeks before harvest reduced postharvest gray mold by approximately $50 \%$. When fungicides were applied repeatedly after berry set either in mixtures or alternated with fungicides of different mode of action classes, postharvest gray mold was reduced by about $50 \%$ using a commercial air-blast sprayer and by 70 to $87 \%$ using a hand-held sprayer that was directed into the clusters. The fungicide sensitivity of isolates collected in numerous vineyards indicated those with reduced sensitivity to all of the tested fungicides, except FEN, were common. The efficacy of preharvest fungicide regimes was not sufficient to replace postharvest sulfur dioxide fumigation.
\end{abstract}

Fungicides are typically applied in vineyards to control bunch rot caused by Botrytis cinerea $(11,28,38)$. However, they are also applied in table grape vineyards for another purpose, the control of postharvest decay caused by this pathogen $(12,17,26)$. Fungicide timing to control gray mold is primarily driven in vineyard environments by the occurrence of rainfall. Rainfall at harvest, an uncommon event in central California, causes abundant production of inoculum and subsequent epiphytotics of this disease in vineyards, and fungicide applications are critically needed when this occurs. Our study examined the benefits of fungicide applications to control postharvest decay during a typically dry summer season in the arid San Joaquin Valley of California with irrigation as the main source of moisture.

Corresponding author: J. L. Smilanick

E-mail: joe.smilanick@ars.usda.gov

Accepted for publication 13 October 2009.

doi:10.1094/PDIS-94-2-0250

This article is in the public domain and not copyrightable. It may be freely reprinted with customary crediting of the source. The American Phytopathological Society, 2010.
Most of the table grape production in the United States is located in the San Joaquin Valley, and B. cinerea routinely causes substantial postharvest decay if measures to control it, such as sulfur dioxide fumigation (32), are not taken. Even a single infection within a table grape package can cause severe losses, since the pathogen can grow at cold storage temperatures $(-0.5$ to $0.5^{\circ} \mathrm{C}$ ) and spread from infected to healthy berries by aerial mycelial growth. Inspection standards state that in the United States, the number of infected berries within packages cannot exceed $0.5 \%$ at the time of shipment or $1.0 \%$ at their destination (3), although in practice even lower tolerances exist between sellers and buyers. In order to meet these stringent tolerances, postharvest sulfur dioxide fumigation is a ubiquitous practice in this industry (32). It is very effective, but causes bleaching injuries (36) and alters the flavor of the grapes (31), and its use raises issues of regulatory concern such as sulfite sensitivity in some consumers, the influence of discharged gas on air quality, and worker safety (30).

Few studies describing the use of vineyard fungicides to control postharvest gray mold have been published, and the fungi- cides described in most of these studies are no longer in common use. Harvey (21) concluded that veraison (the period of berry maturity characterized by softening and color development) and near-harvest applications of captan reduced the number of postharvest gray mold infections that developed in storage up to $90 \%$. Earlier applications of captan during flowering did not improve its effectiveness. In South Africa, De Kock and Holz (12) applied folpet, chlorothalonil, procymidone, prochloraz, thiram, vinclozolin, and iprodione to table grapes before harvest in various schedules to control postharvest gray mold. Programs employing applications of these fungicides from bunch closure and later, typically reduced postharvest decay by about $50 \%$, while those applied earlier, from flowering to a berry size of $4 \mathrm{~mm}$, were ineffective. Working in Chile, Franck et al. (17) reported a single application of fenhexamid 1 day before harvest reduced postharvest gray mold from 57.1 to $11.9 \%$ on 'Thompson Seedless' grapes and from 79.1 to $19.4 \%$ on 'Redglobe' grapes. It is not known how effectively the newer "reduced-risk" fungicides (those deemed by the U.S. Environmental Protection Agency to pose less risk to human health and the environment than prior conventional alternatives), registered to control bunch rot on wine grapes and $B$. cinerea on other crops $(1,15,34)$, would reduce postharvest gray mold on table grapes.

The objectives of our work were to determine the effectiveness of fungicides to inhibit the growth of $B$. cinerea in vitro and to control postharvest gray mold. Gray mold control was assessed in laboratory tests with inoculated berries and in commercial vineyard experiments with natural infections. Although little information about fungicide influence on postharvest decay has been published, many table grape growers in California repeatedly apply one or more of the registered fungicides, including the reduced-risk fungicides pyrimethanil (PYR), cyprodinil (CYP), fenhexamid (FEN), pyraclostrobin (PS), and boscalid (BO), and the older conventional fungicides thiophanate methyl (THM) and iprodione (IPR). Therefore, we also determined the fungicide sensitivity of many $B$. cinerea isolates collected in table grape vineyards, particularly since resistance to them has 
been reported elsewhere (28). B. cinerea is a classical "high-risk pathogen" (6); consequently, intensive use of reduced-risk fungicides, all of which are site-specific inhibitors, would be expected to lead to rapid selection of resistant isolates. Furthermore, there may be large natural variations in the sensitivity of the pathogen population to these fungicides, but it is presently unknown.

\section{MATERIALS AND METHODS}

Fungicide sensitivity of $B$. cinerea isolates. Five fungicide-sensitive control isolates were used to estimate the baseline fungicide sensitivity of $B$. cinerea. They were isolated in 1988 from decayed kiwi fruit from vineyards where only benomyl had been used. In 2007 and 2008, infected berries were collected from numerous table grape vineyards from Fresno, Tulare, and Kern counties. A single hyphal tip from each of approximately 85 to 90 isolates grown on water agar was excised, cultured on potato dextrose agar (PDA) at $24^{\circ} \mathrm{C}$, and used to determine fungicide sensitivity. The fungicides used in this and other tests and many of their characteristics are listed in Table 1. The fungicides in media were from commercial formulations. Final concentrations in PDA were: (i) $0.05,0.1,0.5$, or $1.0 \mathrm{mg}$ of PYR liter $^{-1}$; (ii) a mixture of PS and $\mathrm{BO}$ at $0.34+0.66$, $0.68+1.32,1.36+2.64$, or $2.0+4.0 \mathrm{mg} \mathrm{liter}^{-1}$ (these fungicides were used together because their commercial formulation is a mixture); (iii) $0.5,1.0,2.0$, or $3.0 \mathrm{mg}$ of CYP liter ${ }^{-1}$; (iv) 1.0, 2.0, 4.0, or $8.0 \mathrm{mg}$ of IPR liter ${ }^{-1}$; (v) 10.0, 20.0, 30.0, or $40.0 \mathrm{mg}$ of THM liter ${ }^{-1}$; and (vi) $0.05,0.1,0.2$, or $0.4 \mathrm{mg}$ of FEN liter ${ }^{-1}$. The inoculum of each isolate was prepared from 2-week-old cultures on PDA, the inoculum density was adjusted to 400,000 conidia $\mathrm{ml}^{-1}$, and a 20$\mu \mathrm{l}$ droplet was placed on the agar, with five isolates per plate. Plates were incubated for $48 \mathrm{~h}$ at $24^{\circ} \mathrm{C}$, then colony diameters were measured with a digital caliper and the concentrations that reduced colony diameter by $50 \%\left(\mathrm{EC}_{50}\right)$ for each fungicide were calculated. The $\mathrm{EC}_{50}$ was determined on PDA, with the exception of PYR, where a synthetic agar medium (ASP) containing L-asparagine was used (23). Tests were repeated three times and the $\mathrm{EC}_{50}$ values were determined by regression.

Fungicide effectiveness on detached berries. Single detached 'Thompson Seedless' berries were prepared from freshly harvested grapes by clipping the berries from the rachis, so as to leave a portion of the stem on the berries to avoid making a large wound when they were detached. Fungicides were applied with an air-brush sprayer to berries until runoff at four intervals: (i) $48 \mathrm{~h}$ before inoculation; (ii) $24 \mathrm{~h}$ before inoculation; (iii) $24 \mathrm{~h}$ after inoculation; or (iv) $48 \mathrm{~h}$ after inoculation. The berries were inoculated by spraying them to runoff with a water suspension containing 250,000 conidia of B. cinerea $\mathrm{ml}^{-1}$. Rates of the fungicides were the concentrations applied in vineyards when the label maximum rates are used in a volume of 1,900 liters $\mathrm{ha}^{-1}$. Applied were: (i) paraffinic oil, $9.6 \% \mathrm{vol} / \mathrm{vol}$; (ii) thiophanate methyl, $0.6 \mathrm{~g} \mathrm{liter}^{-1}$; (iii) PS+BO, 0.059 and $0.116 \mathrm{~g} \mathrm{liter}^{-1}$, respectively (PS+BO were used at $54.2 \%$ of their current registered maximum rates.); (iv) IPR, $0.5 \mathrm{~g}$ liter $^{-1}$; (v) CYP, 0.27 g liter $^{-1}$; (vi) PYR, 0.37 g liter $^{-1}$; (vii) FEN, 0.29 g liter $^{-1}$; and water alone as a control. Each was applied to three replicates of 50 berries each. After treatment, the berries were stored for 2 weeks at $15^{\circ} \mathrm{C}$ and the number of infected berries was counted. The experiment was repeated three times. It was repeated a fourth time without inoculation of the grapes, and residues of FEN, PYR, CYP, IPR, and PS+BO were determined.

Fungicide residues were quantified according to Lee et al. (27). Fifty grams of a homogenized sample of the grapes was extracted with $100 \mathrm{ml}$ of acetonitrile for 3 min using a blender. Three replicates were prepared. The acetonitrile was filtered, then aliquots were removed for organochlorine or organonitrogen fungicide analysis. Organochlorine fungicide extracts were further purified using florisil solid phase extraction columns and analyzed by gas chromatograph (model 3800, Varian Inc., Palo Alto, CA) equipped with electrolytic conductivity detector having dual column confirmation. Organonitrogen fungicide extracts were exchanged into acetone and analyzed without further purification by gas chromatograph (model 3400, Varian Inc.) equipped with flame photometric detector and thermionic specific detector without further purification.

Fungicide effectiveness in an experimental vineyard. Two experiments were conducted in a 30-year-old 'Thompson Seedless' vineyard in Parlier, CA at the USDA ARS San Joaquin Agricultural Sciences Center. The vines were bilateral cordon trained, spur pruned on a standard " $\mathrm{T}$ " trellis system, and spaced $2.1 \mathrm{~m}$ between vines and $3.6 \mathrm{~m}$ between rows. Vines were drip irrigated in the vine row at a level of approximately $80 \%$ of the evapotranspiration rate (ET). The vines were not girdled, and no gibberellic acid was applied to the clusters. The experiment had five replicate plots in a Latin square design with five vines in each plot, with two buffer vines at each end of the plot and

Table 1. Fungicides evaluated to control postharvest gray mold of table grapes ${ }^{q}$

\begin{tabular}{|c|c|c|c|c|c|c|c|c|}
\hline \multirow[b]{2}{*}{ Common name } & \multirow[b]{2}{*}{ Product } & \multirow{2}{*}{$\begin{array}{l}\text { Rate } \\
\left(\text { ha }^{-1}\right)\end{array}$} & \multirow{2}{*}{$\begin{array}{c}\text { AI (\% by } \\
\text { weight) }\end{array}$} & \multicolumn{3}{|c|}{ FRAC classifications $^{r}$} & \multirow[b]{2}{*}{ Re-entry } & \multirow[b]{2}{*}{ PHI } \\
\hline & & & & Group & Code & Resistance risk & & \\
\hline 1. Captan & Captan & $4.50 \mathrm{~kg}$ & 48.9 & Phthalimides & M4 & Low & 72 & 0 \\
\hline 2. Cyprodinil & Vangard ${ }^{t}$ & $0.71 \mathrm{~kg}$ & 75.0 & Aniline-pyrimidine & 9 & Medium & 12 & 7 \\
\hline 3. Cyprodinil & Switch $^{t}$ & $1.02 \mathrm{~kg}$ & 37.5 & Aniline-pyrimidine & 9 & Medium & \multirow{2}{*}{\multicolumn{2}{|c|}{ Not registered }} \\
\hline + fludioxonil & & & 25.0 & Phenylpyrrole & 12 & Low to medium & & \\
\hline 4. Fenhexamid & Elevate $^{u}$ & $1.13 \mathrm{~kg}$ & 50.0 & Hydroxyanilide & 17 & Low to medium & 12 & 0 \\
\hline 5. Iprodione & Rovral $^{v}$ & 2.40 liter & 41.6 & Dicarboximide & 2 & Medium to high & 48 & 7 \\
\hline 6. Paraffinic oil & JMS Stylet oil ${ }^{\mathrm{w}}$ & 18.90 liter & 97.1 & Mineral oil & $\mathrm{NC}$ & Resistance unknown & 4 & 14 \\
\hline 7. Potassium bicarbonate & Kaligreen $^{\mathrm{x}}$ & $5.70 \mathrm{~kg}$ & 82.0 & Bicarbonate & $\mathrm{NC}$ & Resistance unknown & 4 & 1 \\
\hline 8. Pyraclostrobin & Pristiney & 0.90 or & 12.8 & Methoxy-carbamate & 11 & High & 24 & 14 \\
\hline+ boscalid & & $1.66 \mathrm{~kg}$ & 25.2 & Pyridine-carboxamide & 7 & Medium & & \\
\hline 9. Pyrimethanil & Scala $\mathrm{SC}^{\mathrm{v}}$ & 1.30 liter & 54.6 & Anilinopyrimidine & 9 & Medium & 24 & 7 \\
\hline 10. Thiophanate methyl & Topsin M $70 \mathrm{WP}^{\mathrm{z}}$ & $1.70 \mathrm{~kg}$ & 70.0 & Thiophanate & 1 & High & 168 & 14 \\
\hline
\end{tabular}

${ }_{\mathrm{q}}^{\mathrm{q}}$ Re-entry is the period in $\mathrm{h}$ between fungicide application and entry into the vineyard and PHI is the interval in days between the last fungicide application and harvest for the California registration of these products.

${ }^{\mathrm{r}}$ Fungicide Resistance Action Committee (19) chemical group, group code, and risk of developing resistance for fungicides used in these studies.

s Micro Flo Co., LLC, Memphis, TN.

${ }^{\mathrm{t}}$ Syngenta Crop Protection, Greensborough, NC.

"Arvesta Life Science, Cary, NC.

${ }^{v}$ Bayer Crop Science, Research Triangle Park, NC.

${ }^{\mathrm{w}}$ JMS Flower Farms, Vero Beach, FL.

x Toagosei Co. Ltd., Tokyo, Japan.

y BASF, Research Triangle Park, NC. In detached berry tests, Pristine was used at $0.90 \mathrm{~kg} \mathrm{ha}^{-1}$; in all other tests, the current maximum rate of $1.66 \mathrm{~kg}$ ha-1 was used.

${ }^{\text {z }}$ United Phosphorus Inc., King of Prussia, PA. 
two buffer rows between treated rows. Materials were applied with an all terrain vehicle-mounted, low-pressure, hand-gun sprayer in a volume of 1,900 liters $\mathrm{ha}^{-1}$. The canopy was pruned repeatedly during the growing season to facilitate coverage of the clusters by the fungicides. All treatments except paraffinic oil contained the surfactant Latron B-1956 (Dow AgroSciences LLC, Indianapolis, IN) at $0.3 \mathrm{ml}$ liter $^{-1}$. The first spray was just after flowering, the second spray was just before bunch closure, the third spray was at veraison (onset of berry maturity and softening), and the final spray was 2 weeks before harvest. In 2007, CYP, FEN, PS+BO, THM, IPR, and PYR were applied at the rates described in Table 1. In 2008, the same fungicides were applied and a CYP + fludioxonil mixture was added. This fungicide (Switch) was not registered in California at the time this work was conducted (approval anticipated in 2010). At harvest, one box containing 10 cluster bags that contained approximately $0.6 \mathrm{~kg}$ of grapes each was prepared from each of the five replicate plots. The percentage of decayed berries was determined after approximately 2 months of storage at $0.5^{\circ} \mathrm{C}$ by counting the number of infected berries.

Fungicide effectiveness in commercial vineyards. The first and second trials were conducted in mature 'Redglobe' and 'Autumn Royal' vineyards approximately 15 years old near Delano, CA. The influence of a single fungicide application 2 weeks before harvest to control postharvest decay was determined. Vine spacing, trellis system, and irrigation were similar to that described in the experimental 'Thompson Seedless' vineyard. Powdery mildew was controlled with micronized and dusting sulfur. Fungicide treatments were applied once, 2 weeks before harvest. Four replicate plots in a complete randomized block with five vines in each plot were used, with two buffer vines at each end of the plot and two buffer rows between treated rows. Clusters were tipped and berries were thinned according to standard grower practices. All treatments contained Latron B1956 at $0.3 \mathrm{ml} \mathrm{liter}^{-1}$. CYP, PS+BO, and PYR were applied once 2 weeks before harvest. All treatments were applied with a commercial air-assisted tree and vine sprayer (Pul-Blast, Rears Manufacturing, Inc., Eugene OR). The sprayer had three nozzles per side (two model D6 core, one model D5 core, with a 46 core to produce a hollow cone spray). The sprayer passed each replicate plot twice, once on the south side and again on the east side. It operated at $690 \mathrm{kPa}$, applied 1,900 liters $\mathrm{ha}^{-1}$, and was pulled at $45.6 \mathrm{~m} \mathrm{~min}^{-1}$. Visibly decayed or damaged berries were removed during harvest. Two boxes with 10 perforated polyethylene cluster bags each were prepared from each plot; each bag contained approximately $0.6 \mathrm{~kg}$ of grapes composed of portions of 3 to 5 clusters. The percentage of decayed berries was determined by counting the number infected once after $1^{\circ} \mathrm{C}$ storage for 1 month after harvest.

A third trial was conducted in a 6-yearold commercial 'Ruby Seedless' table grape vineyard near Delano. Postharvest gray mold is particularly troublesome on this variety. Numerous surface cracks are commonly present on this cultivar, a feature associated with susceptibility to $B$. cinerea infection (35). Vine spacing, trellis system, and irrigation were similar to that described in the experimental 'Thompson Seedless' vineyard. Vines were girdled at berry set, and gibberellic acid was applied twice, once at 85 to $90 \%$ bloom $\left(2.5 \mathrm{~g} \mathrm{ha}^{-1}\right)$ to increase berry size and reduce fruit set within clusters and again following berry set $\left(20 \mathrm{~g} \mathrm{ha}^{-1}\right)$ to increase berry size and weight. Clusters were tipped and berries were thinned according to standard grower practices, and the canopy was hedged mechanically to facilitate exposure of the clusters. Powdery mildew was controlled with micronized and dusting sulfur. Treatments were applied to six-vine plots in a randomized complete block design with four replications. All were either applied once, 2 weeks before harvest, or twice, when the berries were about $0.5 \mathrm{~cm}$ in diameter and again 14 days before harvest The vines were mechanically hedged and basal leaves were removed to expose clusters several days before the second application. CYP, potassium bicarbonate, PYR, PS + boscalid, FEN, captan, and paraffinic oil were applied at rates described in Table 1. All treatments except paraffinic oil contained the surfactant Latron B-1956 at 32 $\mathrm{ml}$ per 100 liters. The trial location received $8 \mathrm{~mm}$ of rain on 21 May 2006. The fruit were harvested on 7 September 2006. Visibly decayed or damaged berries were removed during harvest. One box with 9 perforated polyethylene cluster bags, each containing approximately $0.6 \mathrm{~kg}$ composed of portions of 3 to 5 clusters, was prepared from each plot. Three replicate $0.5-\mathrm{kg}$ samples of berries from each fungicide treatment were collected for residue analysis at harvest. Residues of CYP, captan, PYR, FEN, BO, and PS were determined from a 1-kg sample of grapes from each of four replicate plots by the methods previously described. The percentage of decayed berries was determined by counting the infected berries once after $1{ }^{\circ} \mathrm{C}$ storage for 1 month after harvest.

A fourth trial was conducted in a 15year-old commercial 'Thompson Seedless' table grape vineyard near Delano. The vines were bilateral cordon trained, spur pruned on a standard " $\mathrm{T}$ " trellis system, and spaced $2.1 \mathrm{~m}$ between vines and $3.6 \mathrm{~m}$ between rows. Vines were drip irrigated in

Table 2. Influence of preharvest fungicide applications to control postharvest gray mold on 'Thompson Seedless' grapes in 2007 and $2008^{\mathrm{v}}$

\begin{tabular}{|c|c|c|c|c|c|c|}
\hline \multirow[b]{2}{*}{ After flowering } & \multirow[b]{2}{*}{ Bunch closure } & \multirow[b]{2}{*}{ Onset of softening } & \multirow{2}{*}{$\begin{array}{l}2 \text { Weeks } \\
\text { before harvest }\end{array}$} & \multicolumn{3}{|c|}{ Postharvest decay $(\%)^{\mathrm{w}, \mathrm{x}}$} \\
\hline & & & & Gray mold & Other ${ }^{y}$ & Total $^{\mathbf{z}}$ \\
\hline \multicolumn{7}{|l|}{2007} \\
\hline 1. Water & Water & Water & Water & $5.5 \mathrm{a}$ & $1.2 \mathrm{a}$ & $6.7 \mathrm{a}$ \\
\hline 2. FEN & $\mathrm{PS}+\mathrm{BO}$ & THM & CYP & $1.9 \mathrm{~b}$ & $1.0 \mathrm{ab}$ & $2.9 \mathrm{~b}$ \\
\hline 3. THM & IPR & $\mathrm{PS}+\mathrm{BO}$ & FEN & $1.3 \mathrm{~b}$ & $0.8 \mathrm{c}$ & $2.1 \mathrm{bc}$ \\
\hline 4. CYP+FEN & $\mathrm{PS}+\mathrm{BO}+\mathrm{CYP}$ & IPR & $\mathrm{FEN}+\mathrm{PS}+\mathrm{BO}$ & $0.7 \mathrm{c}$ & $0.9 \mathrm{~b}$ & $1.6 \mathrm{c}$ \\
\hline \multicolumn{7}{|l|}{2008} \\
\hline 1. Water & Water & Water & Water & $5.4 \mathrm{a}$ & $3.9 \mathrm{a}$ & $9.3 \mathrm{a}$ \\
\hline 2. FEN & $\mathrm{PS}+\mathrm{BO}$ & THM & CYP & $1.6 \mathrm{bc}$ & $2.7 \mathrm{~b}$ & $4.2 \mathrm{~b}$ \\
\hline 3. THM & IPR & $\mathrm{PS}+\mathrm{BO}$ & FEN & $2.1 \mathrm{~b}$ & $2.2 \mathrm{~b}$ & $4.2 \mathrm{~b}$ \\
\hline 4. $\mathrm{CYP}+\mathrm{FEN}$ & $\mathrm{PS}+\mathrm{BO}+\mathrm{CYP}$ & IPR & $\mathrm{FEN}+\mathrm{PS}+\mathrm{BO}$ & $1.1 \mathrm{c}$ & $1.9 \mathrm{~b}$ & $2.9 \mathrm{~b}$ \\
\hline 5. FEN & $\mathrm{CYP}+\mathrm{FLU}$ & $\mathrm{PS}+\mathrm{BO}$ & PYR & $1.4 \mathrm{bc}$ & $1.8 \mathrm{~b}$ & $3.2 \mathrm{~b}$ \\
\hline
\end{tabular}

${ }^{v}$ Applications were done at flowering (mid-May), bunch closure (mid-June), the onset of berry softening or veraison (Mid-July), and 2 weeks before harvest (mid-August). Thiophanate methyl (THM), iprodione (IPR), cyprodinil (CYP), pyraclostrobin + boscalid (PS+BO), pyrimethanil (PYR), or fenhexamid (FEN) was applied at rates described in Table 1. No injury to any berries was observed in 2007. Berry lenticels were dark brown in color among grapes harvested from regime 3 in 2008.

${ }^{\mathrm{w}}$ One box containing 10 cluster bags was harvested from each of five replicate plots, stored at $0.5^{\circ} \mathrm{C}$ without sulfur dioxide fumigation, and the number of infected berries was counted approximately 7 weeks after harvest.

${ }^{\mathrm{x}}$ An arcsine transformation was done before an analysis of variance was applied. Actual values are shown. Values followed by different letters within each year are significantly different by Tukey's HSD $(P=0.05)$.

${ }^{y}$ Decay by pathogens other than Botrytis cinerea.

${ }^{\mathrm{z}}$ The total of decay by $B$. cinerea and other pathogens. 
the vine row and furrow irrigated in alternating row middles at a level of approximately $80 \%$ ET. Vines were girdled at berry set to increase berry size, and gibberellic acid was applied to the clusters at 85 to $90 \%$ bloom $\left(2.5 \mathrm{~g} \mathrm{ha}^{-1}\right)$ to reduce fruit set, and again following berry set (20.0 $\left.\mathrm{g} \mathrm{ha}^{-1}\right)$ to increase berry length and weight. Powdery mildew was controlled with micronized and dusting sulfur. Although the vines were mechanically hedged before the applications, the vineyard canopy was dense. Fungicide treatments were applied four times (Table 2: at the end of flowering, at bunch closure, at the onset of veraison, and 2 weeks before harvest) to six-vine plots in a latin square design with five replications. CYP, FEN, PS+BO, THM, IPR, and PYR were ap- plied at the rates described in Table 1 with the commercial sprayer described previously. Visibly decayed or damaged berries were removed during harvest. Two boxes were prepared from each plot. Each box contained nine perforated polyethylene cluster bags, each bag containing approximately $0.6 \mathrm{~kg}$ of grapes composed of portions of 3 to 5 clusters. The percentage of decayed berries was determined by counting infected berries once after $1^{\circ} \mathrm{C}$ storage for 1 month after harvest.

Statistical analysis. To improve homogeneity of variance, an arcsine transformation was applied to the square root of the proportion of infected berries before an analysis of variance was conducted. Fisher's protected LSD or Tukey's HSD $(P$ $=0.05$ ) tests were used to separate means.
$\mathrm{EC}_{50}$ fungicide concentrations that inhibited colony growth by $50 \%$ were estimated by regression. All analyses employed statistical software (SPSS ver. 16.0 for Windows, SPSS Inc., Chicago, IL).

\section{RESULTS}

The fungicide that was most inhibitory to the growth of fungicide-sensitive isolates of $B$. cinerea on PDA was FEN, while THM was the least inhibitory. $\mathrm{EC}_{50}$ values of THM, IPR, CYP, PS+BO, PYR, and FEN were 12.4, 2.5, 0.61, 0.29/0.57, 0.26, and $0.17 \mathrm{mg} \mathrm{liter}^{-1}$, respectively. $\mathrm{EC}_{50}$ values of isolates collected from table grape vineyards in 2007 and 2008 (Fig. 1) were variable and higher than those of the fungicide-sensitive control isolates, with the exception of FEN. Isolates with $\mathrm{EC}_{50}$ val-

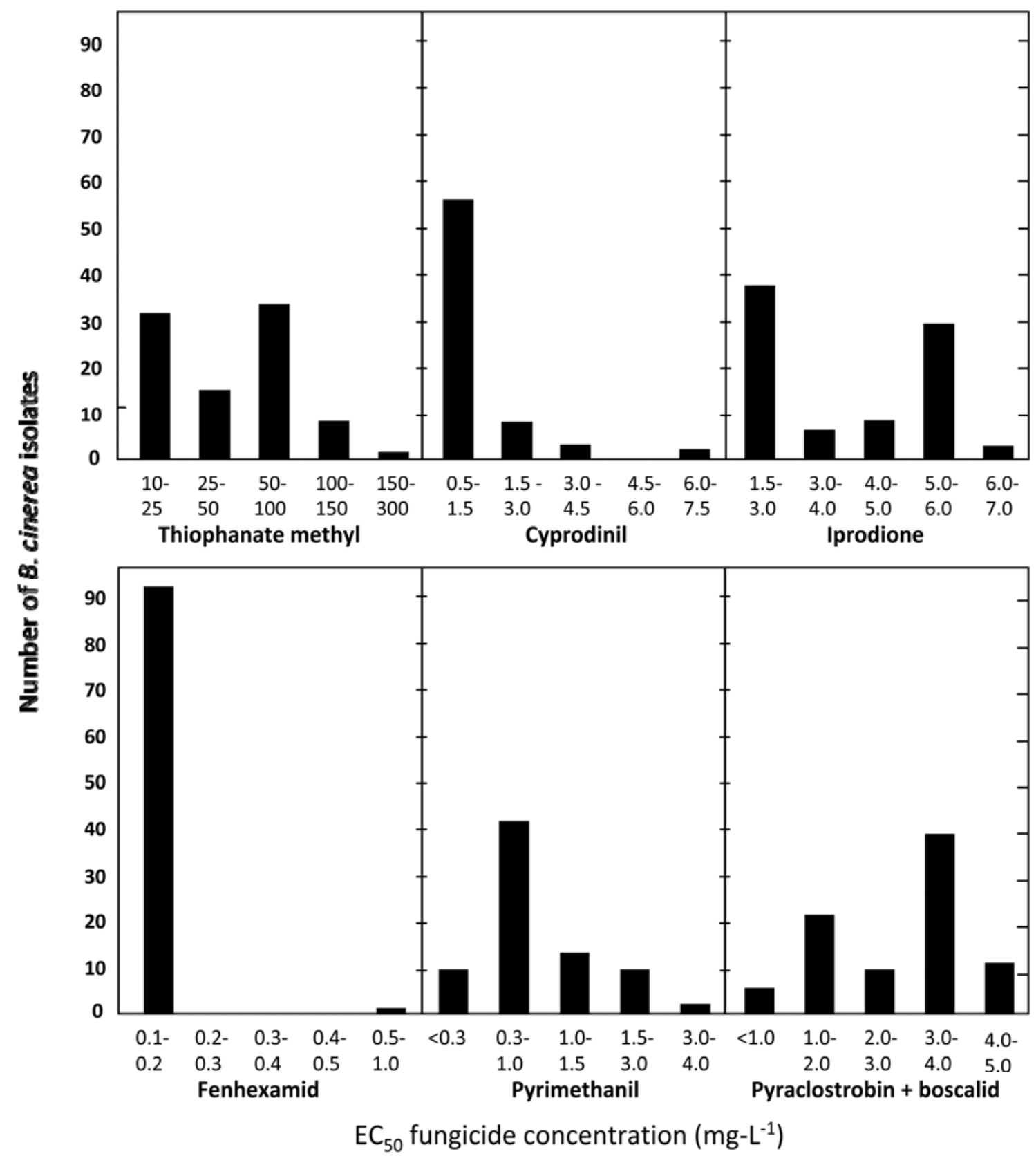

Fig. 1. Fungicide concentrations that reduced colony growth of isolates of Botrytis cinerea by $50 \%\left(\mathrm{EC}_{50}\right)$. Isolates were collected in table grape vineyards in the San Joaquin Valley of California in 2007 and 2008. Isolates were cultured on fungicide-amended potato dextrose agar or, for pyrimethanil, on asparagine agar. 
ues two or more times higher than those of the sensitive isolates were common, while only a single isolate with a relatively high $\mathrm{EC}_{50}$ value to $\mathrm{FEN}$ was found.

In the laboratory experiment where THM, IPR, CYP, PS+BO, PYR, and FEN were applied to runoff to detached 'Thompson Seedless' berries treated before or after inoculation with $B$. cinerea, FEN was the most effective fungicide both as a protective and a curative treatment (Fig. 2). Control of gray mold declined when the fungicides were applied $48 \mathrm{~h}$ after inoculation. Postharvest gray mold was lowest after FEN treatment, followed by PYR, CYP, IPR, PS+BO, and THM. Paraffinic oil did not significantly control gray mold. The effectiveness of PS+BO was underestimated in this test, since we used only $54.2 \%$ of their maximum approved rates. Residues (mg kg-1, \pm SD) of FEN, PYR, CYP, IPR, and PS+BO on the berries in this experiment were $1.11( \pm 0.12), 4.66$ $( \pm 0.76), 5.05( \pm 2.0), 2.61( \pm 0.24)$, and $1.93( \pm 0.18)+0.48( \pm 0.08)$, respectively.
Residues of PS+BO in this test underestimate those expected if we had used their maximum approved rates, since only $54.2 \%$ of the maximum rate (Pristine) was applied.

In the vineyard with optimized management and cluster-directed application of the fungicides, all of the preharvest regimes to 'Thompson Seedless' grapes reduced the number of infected berries significantly, and the magnitude of the reduction was large, by as much as $87 \%$ (Table 2). In the second test, control of gray mold by the treatments was similar (Table 2 ), but berry lenticels were dark brown in color among grapes harvested from regime 3. In both tests, control of fungi other than $B$. cinerea was significant but of a lower magnitude than that of gray mold (Table 2). Most of the decay other than gray mold was caused by Alternaria spp.

In vineyards with commercial management and spray equipment, a single application of CYP, PS+BO, or PYR to 'Autumn Royal' or 'Redglobe' grapes 2 weeks before harvest significantly reduced postharvest gray mold (Table 3). The level of control of gray mold on 'Redglobe' grapes was generally higher than on 'Autumn Royal'.

In a vineyard with commercial management and spray equipment, one or two applications of FEN before harvest to 'Ruby Seedless' grapes significantly reduced postharvest gray mold by approximately $50 \%$, while the effectiveness of the other fungicides was poor (Table 4). Residues of CYP, captan, PYR, FEN, BO, and PS were slightly higher after one early application and a second late application before harvest, compared to a single late application.

In a vineyard with commercial management and spray equipment, applications of $\mathrm{CYP}, \mathrm{PS}+\mathrm{BO}$, or PYR in various regimes to 'Thompson Seedless' grapes significantly reduced postharvest gray mold (Table 5), but the reduction was only 40 to $50 \%$ and less than that observed with similar regimes in the 'Thompson Seedless' vineyard optimized management and custom spray equipment. Decay by fungi

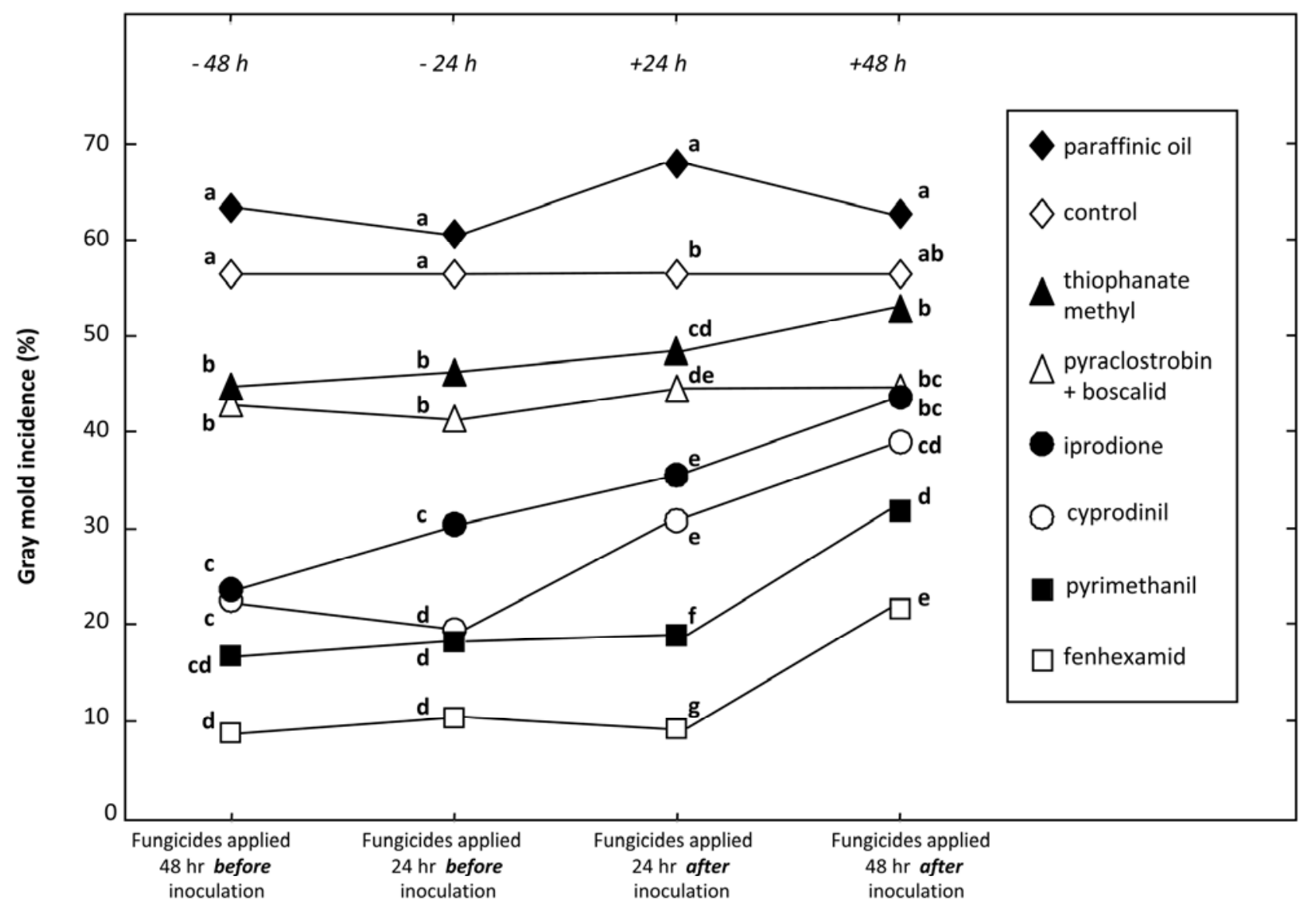

Period between fungicide application and inoculation with $B$. cinerea

Fig. 2. Control of postharvest gray mold on single detached 'Thompson Seedless' table grape berries by fungicides applied to runoff from $48 \mathrm{~h}$ before to $48 \mathrm{~h}$ after their inoculation with Botrytis cinerea. Concentrations (active ingredients): paraffinic oil, $9.6 \%$ by volume; thiophanate methyl, $600 \mathrm{mg} \mathrm{liter}^{-1}$; pyraclostrobin, $59 \mathrm{mg} \mathrm{liter}^{-1}$, and boscalid $116 \mathrm{mg} \mathrm{liter}^{-1}$; iprodione, $500 \mathrm{mg} \mathrm{liter}^{-1}$; cyprodinil, $270 \mathrm{mg} \mathrm{liter}^{-1}$; pyrimethanil, $370 \mathrm{mg} \mathrm{liter}^{-1}$; and fenhexamid, $290 \mathrm{mg}$ liter $^{-1}$. These concentrations are calculated to match those applied at the approved maximum rate of each fungicide in a water volume of 1,900 liters ha $^{-1}$ (Table 1). The control was an application of water alone. Each was applied to three replicates of 50 berries each, and the experiment was repeated three times. Grapes were inoculated by spraying them with a water suspension containing 250,000 conidia of $B$. cinerea $\mathrm{ml}^{-1}$. After treatment, berries were stored for 2 weeks at $15^{\circ} \mathrm{C}$, when the number of infected berries was counted. Since pyraclostrobin and boscalid were used at 54\% of the current approved maximum rate in California, their effectiveness is underestimated in this test. Values within each inoculation interval followed by different letters are significantly different according to Tukey's HSD $(P=0.05)$. 
other than B. cinerea, mostly Alternaria spp., was not controlled.

\section{DISCUSSION}

The origin of $B$. cinerea infections present on berries at harvest is greatly influenced by the environment and cultivar. Following frequent colonization of grapevine flowers early in the growing season, the number of infections declines markedly and a few survive in a quiescent phase until the onset of veraison (8). Holz et al. (24) reported that natural infections by $B$. cinerea were located at the base of the berry and the pedicel and rarely elsewhere. In the Western Cape Province of South Africa, where environmental conditions are relatively arid and similar to those of the San Joaquin Valley of California, De Kock and Holz (12) reported that most infections of table grapes that caused postharvest decay occurred after bunch closure. Many late-season infections are the consequence of the inoculation of maturing berries via injuries made by insects, birds, natural cracks or pores, and other mechanical injuries caused by viticulture operations $(8,12)$. In contrast to wine grapes, table grapes are subject to manual harvest, trimming to remove defective berries, and packaging by hand into boxes, followed by long storage; these processes distribute inoculum and cause injuries that facilitate infection. Most investigators reported that vineyard applications of fungicides to table grapes after the onset of veraison were effective for controlling postharvest decay, while the effectiveness of earlier-season applications was less consistent (12). We accepted these conclusions in our work, and every application regime we evaluated included a late fungicide application 2 weeks before harvest.

Table 3. Influence of a single preharvest fungicide application to control postharvest decay of 'Redglobe' and 'Autumn Royal' grapes ${ }^{\mathrm{x}}$

\begin{tabular}{lcc}
\hline & \multicolumn{2}{c}{ Total postharvest decay $(\%)^{\mathbf{y}, \mathbf{z}}$} \\
\cline { 2 - 3 } & Redglobe & Autumn Royal \\
\hline Control & $7.4 \mathrm{a}$ & $12.3 \mathrm{a}$ \\
PS+BO & $3.2 \mathrm{~b}$ & $9.1 \mathrm{ab}$ \\
PYR & $1.7 \mathrm{~b}$ & $7.8 \mathrm{~b}$ \\
CYP & $3.2 \mathrm{~b}$ & $5.9 \mathrm{~b}$ \\
\hline
\end{tabular}

${ }^{x}$ Fungicides were applied one time 2 weeks before harvest. The fungicides were cyprodinil (CYP), pyraclostrobin + boscalid (PS+BO), and pyrimethanil (PYR) applied at rates described in Table 1.

${ }^{\mathrm{y}}$ Two boxes containing 10 cluster bags were harvested from each of four replicate plots, stored at $0.5^{\circ} \mathrm{C}$ without sulfur dioxide fumigation, and the number of infected berries was counted approximately 1 month after harvest. Most of the decay was caused by Botrytis cinerea.

${ }^{\mathrm{z}}$ Analysis of variance was applied to arcsine of the square root of the proportion of infected berries. Actual values are shown. Values followed by different letters are significantly different by Tukey's HSD $(P=0.05)$.
Fungicide treatments applied in the vineyard are important to reduce the number of infections present at harvest and after harvest during storage and marketing $(17,25)$. Fungicides can provide disease control through both pre- and postinfection activity. In our laboratory tests with detached berries, FEN, PYR, CYP, and IPR all exhibited protectant and curative activity, although curative activity after $48 \mathrm{~h}$ had declined.

In our work to assess fungicide performance with detached berries, postharvest gray mold was lowest after FEN treatment, followed by PYR, CYP, IPR, $\mathrm{PS}+\mathrm{BO}$, and THM. It is likely the effectiveness of $\mathrm{PS}+\mathrm{BO}$ was underestimated in this experiment, since the rate used was only $54.2 \%$ of the maximum rate approved in California. The performance of the fun- gicides was similar whether they were applied either 48 or $24 \mathrm{~h}$ before inoculation or $24 \mathrm{~h}$ afterward; it declined markedly when applied $48 \mathrm{~h}$ after inoculation. In general, effectiveness was negatively correlated with the $\mathrm{EC}_{50}$ values of the control isolates we observed on agar media, which were similar to the baseline values of these fungicides to $B$. cinerea reported by others (28). In similar work with detached berries by Serey et al. (39), the postinoculation activity (curative) of the fungicides captan, CYP, fludioxonil, and BO was shorter (less than $24 \mathrm{~h}$ ) than that of the fungicides evaluated in our work. Regarding protective activity, only a mixture of fludioxonil and CYP had persistent protective activity in their work. The berries were protected from subsequent infec-

Table 4. Influence of preharvest fungicide applications to control postharvest gray mold on 'Ruby Seedless' grapes and fungicide residues ${ }^{\mathrm{w}}$

\begin{tabular}{llcc}
\hline Treatment $^{\mathbf{x}}$ & Timing & Gray $\mathbf{~ m o l d ~}(\boldsymbol{\%})$ & Residue $^{\mathbf{y}} \mathbf{\mathbf { m ~ k g } ^ { - 1 } ) ^ { \mathbf { z } }}$ \\
\hline Control & Early and late & 15.0 & $\ldots$ \\
Control & Late & 19.2 & $\ldots$ \\
Paraffinic oil & Early and late & 17.3 & $\ldots$ \\
Paraffinic oil & Late & 20.4 & $\ldots$ \\
PS+BO & Early and late & 21.0 & 1.01 Boscalid/0.27 pyraclostrobin \\
PS+BO & Late & 21.5 & 0.91 Boscalid/0.22 pyraclostrobin \\
CYP & Early and late & 16.5 & 0.69 Cyprodinil \\
CYP & Late & 21.8 & 0.48 Cyprodinil \\
CAP & Early and late & 13.7 & 2.03 Captan \\
CAP & Late & 15.9 & 1.48 Captan \\
PBC & Early and late & 18.2 & $\ldots$ \\
PBC & Late & 14.5 & $\ldots$ \\
PYR & Early and late & 17.2 & 2.49 Pyrimethanil \\
PYR & Late & 12.0 & 2.40 Pyrimethanil \\
FEN & Early and late & 5.9 & 0.96 Fenhexamid \\
FEN & Late & 10.9 & 0.87 Fenhexamid \\
LSD $(P=0.05)$ & & 4.7 & \\
\hline
\end{tabular}

${ }^{\mathrm{w}}$ All materials were applied with a commercial air-blast sprayer.

${ }^{x}$ Paraffinic oil, potassium bicarbonate (PBC), captan (CAP), cyprodinil (CYP), pyraclostrobin + boscalid (PS+BO), pyrimethanil (PYR), and fenhexamid (FEN) were applied at rates described in Table 1.

y Timing: Early $=$ before bunch closure, Late $=2$ weeks before harvest. Two weeks after the late application, two boxes containing 10 cluster bags were harvested from each of five replicate plots, stored at $0.5^{\circ} \mathrm{C}$ without sulfur dioxide fumigation, and the number of infected berries was counted 45 days after harvest. Most decay was caused by Botrytis cinerea.

${ }^{\mathrm{z}}$ Residues were determined using berries harvested 3 weeks after the late application.

Table 5. Influence of preharvest fungicide applications to control postharvest gray mold on 'Thompson Seedless' grapes

\begin{tabular}{lllccc}
\hline \multirow{2}{*}{$\begin{array}{l}\text { After } \\
\text { flowering }\end{array}$} & \multirow{2}{*}{$\begin{array}{l}\text { Bunch } \\
\text { closure }\end{array}$} & \multirow{2}{*}{$\begin{array}{l}\text { Weeks } \\
\text { before harvest }\end{array}$} & Gray mold & Other $^{\mathbf{y}}$ & Total $^{\mathbf{z}}$ \\
\cline { 4 - 6 } & Water & Water & $16.2 \mathrm{a}$ & $6.9 \mathrm{a}$ & $23.1 \mathrm{a}$ \\
1. Water & PS+BO & CYP & $9.8 \mathrm{ab}$ & $6.0 \mathrm{a}$ & $15.8 \mathrm{ab}$ \\
2. FEN & THM & FEN & $8.4 \mathrm{~b}$ & $4.5 \mathrm{a}$ & $13.0 \mathrm{~b}$ \\
3. IPR & PS+BO/CYP & FEN/ PS+BO & $8.3 \mathrm{~b}$ & $5.8 \mathrm{a}$ & $14.1 \mathrm{~b}$ \\
\hline 4. CYP/FEN & &
\end{tabular}

${ }^{v}$ All materials were applied with a commercial tractor-pulled, air-blast sprayer. Applications were made just after flowering (22 May 2007), before bunch closure (14 June 2007), and 2 weeks before harvest (31 July 2007). Cyprodinil (CYP), fenhexamid (FEN), pyraclostrobin + boscalid (PS+BO), thiophanate methyl (THM), iprodione (IPR), and pyrimethanil (PYR) were applied at rates described in Table 1. Berry lenticels were dark brown in color among grapes harvested from treatment regime 3.

${ }^{\text {w }}$ Analysis of variance was applied to arcsine of the square root of the proportion of infected berries. Actual values are shown. Values followed by unlike letters are significantly different by Tukey's HSD $(P=0.05)$.

x Two boxes containing eight cluster bags each were harvested from each of five replicate plots on 28 September 2007 , stored at $0.5^{\circ} \mathrm{C}$ without sulfur dioxide fumigation, and the number of infected berries was counted once approximately 6 weeks after harvest.

${ }^{y}$ Decay by pathogens other than Botrytis cinerea.

${ }^{z}$ The total of decay by B. cinerea and other pathogens. 
tion when inoculation was made up to 14 days after the berries were immersed in this mixture. However, their study differed significantly from ours because they inoculated wounds on the berries that were 2 to $3 \mathrm{~mm}$ in depth, which facilitates rapid infection, while we did not wound berries before we inoculated them.

The fungicide sensitivity of $B$. cinerea isolates collected from table grape vineyards was variable, except in the case of FEN, which was the most inhibitory to the mycelial growth of fungicide sensitive isolates of $B$. cinerea on PDA; THM was the least inhibitory. Isolates with elevated $\mathrm{EC}_{50}$ values that exceeded the $\mathrm{EC}_{50}$ values of sensitive isolates by two times or more were common among all the fungicides except FEN. A single isolate with reduced sensitivity to FEN was found.

Isolates with reduced sensitivity to the fungicides may have been selected by the use of the fungicides, or they may have already existed in the $B$. cinerea populations. The origin or genesis of these isolates is uncertain. All of these fungicides are registered and in common use in the areas where the isolates were collected. In the case of FEN, which was the most consistently effective fungicide to control gray mold in our work, resistance has been reported to develop rapidly and to even exist naturally in $B$. cinerea populations; therefore, the selection of them by this fungicide may be rapid, and resistant isolates could soon dominate the pathogen population of the San Joaquin Valley. Baroffio et al. (5) reported that FENresistant isolates were not detected in an experimental vineyard in Switzerland for the first two seasons of its use, but occurred thereafter and their frequency increased rapidly to $100 \%$ of the population after three additional seasons. Over this period of five seasons, there had been only two FEN applications annually. Leroux et al. (29) found numerous isolates of $B$. cinerea described as "highly resistant" to FEN in French vineyards before the fungicide was introduced. Recent studies using PCR-duplex and specific primers to detect transposable elements on Chilean B. cinerea isolates from different table grape cultivars corroborated the presence of two sibling cryptic populations, transposa and vacuma. Some vacuma isolates had a natural resistance to FEN (14). In vineyards in Chile, $95.3 \%$ of $B$. cinerea isolates $(n=$ 472) were sensitive $\left(\mathrm{EC}_{50}\right.$ less than 0.083 mg liter ${ }^{-1}$ ) to FEN, $1.9 \%$ were less sensitive $\left(\mathrm{EC}_{50}\right.$ of 0.084 to $0.1 \mathrm{mg}$ liter $\left.^{-1}\right)$, and $2.8 \%$ (13 isolates) were resistant with $\mathrm{EC}_{50}$ values of 0.1 to $8.4 \mathrm{mg} \mathrm{liter}^{-1}$ (14). In central California, Ma and Michailides (33) reported that among 234 isolates from various host plants, only four, collected from fig trees, were resistant, with approximately a 20 -fold increase in resistance to FEN, although this fungicide had never been used to treat the trees. They showed that migration of the conidia between two locations separated by $6.5 \mathrm{~km}$ was frequent, and recommended that disease control strategies should be considered at a regional level, since the resistant isolates may spread rapidly to other farms a few kilometers from the original source.

Regarding the levels of sensitivity to the other fungicides, numerous reports indicate it occurs relatively frequently (28). For example, Latorre et al. (26) reported that the $\mathrm{EC}_{50}$ values of CYP to inhibit mycelial growth among isolates classified as resistant was 2.9 to $4.8 \mathrm{mg} \mathrm{liter}^{-1}$, whereas the $\mathrm{EC}_{50}$ values for isolates classified as sensitive were below $0.01 \mathrm{mg}$ liter $^{-1}$. These same resistant isolates showed crossresistance to mepanipyrim and PYR. A loss of efficacy was observed in a table grape vineyard where CYP had been applied alone up to four times per year during two prior growing seasons (25). Accordingly, the authors stated that this was due to the rapid development of highly resistant strains of B. cinerea. Although significant differences in growth rate, sclerotia production, and osmotic sensitivity were found between isolates of $B$. cinerea resistant to anilinopyrimidines, both resistant and susceptible isolates were equally fit (26).

Timing of fungicide applications to control gray mold is primarily driven in vineyard environments by the occurrence of rainfall. Rainfall at harvest, an uncommon event in the San Joaquin Valley of California, causes abundant production of inoculum and epiphytotics of the disease in vineyards, and fungicide applications are critically needed when this rare event occurs. This area, where most of the table grape production in the United States is located, is typically rainless throughout these periods and $B$. cinere $a$ seldom causes significant vineyard bunch rot $(13,40)$, but it routinely causes substantial postharvest decay if measures to control it are not taken. In our work, bunch rot was rare among clusters at the time of harvest, and what was visible was manually removed. Most of the decay observed after cold storage was caused by $B$. cinerea, although some decay by Alternaria, Cladosporium, and Penicillium spp. was also present. We found fungicide applications could markedly reduce postharvest decay, although even under optimized conditions of vineyard canopy management and fungicide coverage, the level of reduction in gray mold incidence was insufficient to warrant elimination of postharvest sulfur dioxide fumigation. Results obtained with a commercial air-blast vineyard sprayer in a commercial vineyard were inferior to those observed in the tests with optimized conditions. Why this occurred is uncertain. The efficacy of the spray programs may have been influenced by the presence of resistant strains of B. cinerea. In our vineyard with optimized conditions, the vineyard canopy was pruned carefully to facilitate coverage of the clusters by the fungicides, and this action both improves spray coverage and itself has been shown to substantially control bunch rot caused by Aspergillus, $B$. cinerea, and other pathogens $(13,37,40)$.

Fungicide residues in all of our work were below maximum residue limits (MRL) for the United States, which are as follows: BO (3.5 mg kg-1), PS (2 $\left.\mathrm{mg} \mathrm{kg}^{-1}\right)$, CYP (2 mg kg-1), captan (50 mg kg-1), PYR ( $\left.5 \mathrm{mg} \mathrm{kg}^{-1}\right)$, and FEN (2 mg kg$\left.{ }^{-1}\right)$ (4). Minimizing these residues on harvested grapes has become increasingly important for marketing purposes. Prior reports indicated the persistence of the residues of some of the newer reduced-risk fungicides in the grapes in vineyards was relatively brief, although reports describing the halflife of these fungicides on grapes are few, but among those already characterized, their persistence is long. Angioni et al. (2) found PYR residues on 'Italia' table grapes had a half-life of about 12 days. In contrast, captan residues on table grapes were much more persistent, with a half-life of 1 month or more (18). Cabras and coworkers (7) reported the half-lives of CYP and tebuconazole on 'Vermentino' grapes in a vineyard were about 7 and 14 days, respectively, while that of fludioxonil and PYR was more than 1 month. In contrast, on tomato fruit on vines, PYR, fludioxonil, and CYP all had relatively short half-lives of $2.8,6.1$, and 6.7 days, respectively $(9,20)$. Conceivably, fungicide residues that persist after harvest would inhibit the spread of the pathogen from infected berries to healthy ones (39). We did not determine residues of the fungicides after storage, but among those characterized, such as PYR, their persistence was long $(7,10)$.

This work describes the impact of several application regimes of currently approved fungicides on the incidence of postharvest decay among table grapes after storage. These products can be expected to reduce the incidence of decayed berries during cold storage by about 50\% when applied with conventional vineyard sprayers, although improvements in coverage would improve this performance. FEN controlled gray mold most effectively in laboratory trials with detached berries, and its $\mathrm{EC}_{50}$ concentration to inhibit growth of $B$. cinerea in culture was lower than that of the other fungicides. An aspect of using these fungicides is the sensitivity of the $B$. cinerea populations in question. We found that some isolates in table grape vineyards in California have a relatively low level of sensitivity to several of the fungicides, indicating resistance may already influence their effectiveness. An exception was FEN, for which most isolates were quite sensitive, although the appearance of FENresistant isolates in other parts of the world indicates it should be used so as to minimize the development of resistant isolates (19). Resistance represents a real threat to the successful and prolonged use of this 
fungicide and other fungicides. Antiresistance strategies $(16,22,26)$ include limiting the number of applications per growing season, alternating or using tank mixes of fungicides in different mode of action classes, and monitoring populations of $B$. cinerea in vineyards to detect fungicide-resistant isolates.

If marketing occurs promptly after harvest, the suppression of postharvest gray mold by the fungicides may be adequate. However, even the most effective fungicide regime could not replace the current practice of postharvest sulfur dioxide fumigation during prolonged cold storage. In our work, we examined grapes after cold storage for 1 or 2 months, while with weekly sulfur dioxide fumigation, the spread of gray mold is stopped within packages, making storage for 3 months or longer feasible and common (32). Furthermore, by inclusion of sulfur dioxide generator sheets within table grape packages just before they are shipped from cold storage, sulfur dioxide can be applied after cold storage to provide additional protection during transit and at distribution centers. Even so, there are other reasons to use a fungicide regime. In addition to avoiding bleaching injuries and flavor changes that sulfur dioxide can cause, the fungicides often caused marked reduction in vineyard sour rot before harvest, particularly with the cultivar 'Redglobe' (data not shown). Although infected berries were manually removed at harvest, or severely infected clusters were left unharvested, this represents a substantial loss in berry quality and yield and increases labor costs by prolonging harvest.

\section{ACKNOWLEDGMENTS}

We thank the California Table Grape Commission for grant support, Andrew Pandol for donating the use of vineyards and financial assistance for conducting residue analysis, and Peggy Schrader, Gabriel Verduzco, and Murray Pryor for technical assistance.

\section{LITERATURE CITED}

1. Adaskaveg, J. E., Förster, H., Gubler, W. D., Teviotdale, B. L., and Thompson, D. F. 2005. Reduced-risk fungicides help manage brown rot and other fungal diseases of stone fruit. Calif. Agric. 59:109-114

2. Angioni, A., Sarais, G., Dedola, F., and Caboni, P. 2006. Pyrimethanil residues on table grapes Italia after field treatment. J. Environ. Sci. Health 41:833-841.

3. Anonymous. 1999. United States Standards for Grades of Table Grapes (European or Vinifera Type). U.S. Dep. Agric. Agric. Marketing Serv. p. 14.

4. Anonymous. 2009. International Maximum Residue Level Database. U.S. Dep. Agric. Foreign Agric. Serv., FAS Online. http://www. mrldatabase.com/.

5. Baroffio, C. A., Siegfried, W., and Hilber, U. W. 2003. Long-term monitoring for resistance of Botryotinia fuckeliana to anilinopyrimidine, phenylpyrrole, and hydroxyanilide fungicides in Switzerland. Plant Dis. 87:662-666.

6. Brent, K. J., and Hollomon, D. W. 1998. Fungicide resistance: The assessment of risk.
FRAC Monogr. No. 2, Brussels.

7. Cabras, P., Angioni, A., Garau, V. L., Melis, M., Pirisi, F. M., Minelli, E. V., Cabitza, F., and Cubeddu, M. 1997. Fate of some new fungicides (cyprodinil, fludioxonil, pyrimethanil, and tebuconazole) from vine to wine. J. Agric. Food Chem. 45:2708-2710.

8. Cadle-Davidson, L. 2008. Monitoring pathogenesis of natural Botrytis cinerea infections in developing grape berries. Am. J. Enol. Vitic. 59:387-395.

9. Dadlo, S. 2002. Disappearance of pyrimethanil residues on tomato plants. J. Agric. Food Chem. 50:1089-1091.

10. D’Aquino, S., Schirra, M., Palma, A., Angioni, A., Cabras, P., and Migheli, Q. 2007. Residue levels and effectiveness of pyrimethanil versus imazalil when using heated postharvest dip treatments for control of penicillium decay on citrus fruit. J. Agric. Food Chem. 54:4721-4726.

11. Davies, C., Dundon, C., and Johnstone, R. 2000. Managing Bunch Rots. Aust. Soc. Vitic. Oenol. Adelaide, Australia.

12. De Kock, P. J., and Holz, G. 1994. Application of fungicides against postharvest Botrytis cinerea bunch rot of table grapes in the Western Cape. A. Afr. J. Enol. Vitic. 15:33-40.

13. Duncan, R. A., Stapleton, J. J., and Leavitt, G. M. 1995. Population dynamics of epiphytic mycoflora and occurrence of bunch of wine grapes as influenced by leaf removal. Plant Pathol. 44:956-965.

14. Esterio, M., Auger, J., Ramos, C., and García, H. 2007. First report of fenhexamid resistant isolates of Botrytis cinerea on grapevine in Chile. Plant Dis. 91:768.

15. Förster, H., Driever, G. F., Thompson, D. C., and Adaskaveg, J. E. 2007. Postharvest decay management for stone fruit crops in California using the "reduced-risk" fungicides fludioxonil and fenhexamid. Plant Dis. 91:209-215.

16. Forster, B., and Staub, T. 1996. Basis for use strategies of anilinopyrimidine and phenylpyrrole fungicides against Botrytis cinerea. Crop Prot. 15:529-537.

17. Franck, J., Latorre, B. A., Torres, R., and Zoffoli, J. P. 2005. The effect of preharvest fungicide and postharvest sulfur dioxide use on postharvest decay of table grapes caused by Penicillium expansum. Postharv. Biol. Technol. 37:20-30.

18. Frank, R., Northover, J., and Braun, H. E. 1985. Persistence of captan on apples, grapes, and pears in Ontario, Canada, 1981-1983. J. Agric. Food Chem. 33:514-518

19. Fungicide Resistance Action Committee. 2009. FRAC Code List: Fungicides sorted by mode of action (including FRAC Code numbering). http://www.frac.info/frac/publication/anhang/F RAC_CODE_LIST.pdf

20. Garau, V. L., Angioni, A., Del Real, A., Russo, M., and Cabras, P. 2002. Disappearance of azoxystrobin, pyrimethanil, cyprodinil, and fludioxonil on tomatoes in a greenhouse. J. Agric. Food Chem. 50:1929-1932.

21. Harvey, J. M. 1955. Decay in stored grapes reduced by field applications of fungicides. Phytopathology 45:137-140.

22. Hilber, U. W., and Hilber-Bodmer, M. 1998. Genetic basis and monitoring of resistance of Botryotinia fuckeliana to anilinopyrimidines. Plant Dis. 82:496-500.

23. Hilber, U. W., and Schuepp, H. 1996. A reliable method for testing the sensitivity of $\mathrm{Bo}$ trytis fuckeliana to anilinopyrimidines in vitro. Pestic. Sci. 47:241-247.

24. Holz, G., Gütschow, M., Coertze, S., and Calitz, F. J. 2003. Occurrence of Botrytis cinerea and subsequent disease expression at different positions on leaves and bunches of grape. Plant Dis. 87:351-358.

25. Latorre, B. A., Lillo, C., and Rioja, M. E. 2001. Eficacia de los tratamientos fungicidas para el control de Botrytis cinerea de la vid en funcion de la epoca de aplicacion. Cien. Inv. Agric. 28:61-66.

26. Latorre, B. A., Spadaro, I., and Rioja, M. E. 2002. Occurrence of resistant strains of Botrytis cinerea to anilinopyrimidine fungicides in table grapes in Chile. Crop Prot. 21:957-961.

27. Lee, S. M., Papathakis, M. L., Feng, H.-M C., Hunter, G. F., and Carr, J. E. 1991. Multipesticide residue method for fruits and vegetables: California Department of Food and Agriculture. Fresenius J. Anal. Chem. 339:376-383.

28. Leroux, P. 2004. Chemical control of Botrytis and its resistance to chemical fungicides. Pages 195-222 in: Botrytis: Biology, Pathology and Control. Y. Elad, B. Williamson, P. Tudzynski, and N. Delen, eds. Springer, Netherlands.

29. Leroux, P., Chapeland, F., Desbrosses, D., and Gredt, M. 1999. Patterns of cross-resistance to fungicides in Botryotinia fuckeliana (Botrytis cinerea) isolates from French vineyards. Crop Prot. 18:687-697.

30. Lichter, A., Mlikota Gabler, F., and Smilanick, J. L. 2006. Control of spoilage in table grapes. Stewart Postharv. Rev. 6:1-10.

31. Lichter, A., Zutahy, Y., Kaplonov, T., Aharoni, N., and Lurie, S. 2005. The effect of ethanol dip and modified atmosphere on prevention of Botrytis rot of table grapes. HortTechnology 15:9-16.

32. Luvisi, D., Shorey, H., Smilanick, J. L., Thompson, J., Gump, B. H., and Knutson, J. 1992. Sulfur dioxide fumigation of table grapes. Bull. 1932, Univ. Calif., Div. Agric. Nat. Res.

33. Ma, Z., and Michailides, T. J. 2005. Genetic structure of Botrytis cinerea populations from different host plants in California. Plant Dis. 89:1083-1089.

34. McGrath, M. T. 2004. What are Fungicides The Plant Health Instructor. doi: 10.1094/PHII-2004-0825-01.

35. Mlikota Gabler, F., Smilanick, J. L., Mansour, M., Ramming, D. W., and Mackey, B. E. 2003 Correlations of morphological, anatomical, and chemical features of grape berries with resistance to Botrytis cinerea. Phytopathology 93:1263-1273.

36. Nelson, K. E. 1985. Harvesting and handling California table grapes for market. Bull. 1913 Univ. Calif., Div. Agric. Nat. Res.

37. Percival, D. C., Sullivan, J. A., and Fisher, K. H. 1993. Effect of cluster exposure, berry contact and cultivar on cuticular membrane formation and occurrence of bunch rot (Botrytis cinerea PERS.:Fr.) with 3 Vitis vinifera L. cultivars. Vitis 32:87-97.

38. Rosslenbroich, H.-J., and Stuebler, D. 2000 Botrytis cinerea-history of chemical control and novel fungicides for its management. Crop Prot. 19:557-561.

39. Serey, R. A., Torres, R., and Latorre, B. A. 2007. Pre- and post-infection activity of new fungicides against Botrytis cinerea and other fungi causing decay of table grapes. Cien. Inv. Agric. 34:215-224.

40. Stapleton, J. J., and Grant, R. S. 1992. Leaf removal for nonchemical control of the summer bunch rot complex of wine grapes in the San Joaquin Valley. Plant Dis. 76:205-208.

41. Wicks, T., and Hall, B. 2005. Botrytis fungicides - More research needed on spray timing. South Australian Research and Development Institute. Plant Research Centre, Adelaide, SA http://www.sardi.sa.gov.au/_data/assets/pdf_fi le/0005/46688/botrytis_fungicides.pdf.

On 19 March 2010, this article was changed to reflect the fact that, in some of the experiments, Pristine was used at less than the labeled maximum rate. 